\title{
Quantification of archaea-driven freshwater nitrification from single cell to ecosystem levels
}

\author{
Franziska Klotz ${ }^{1}$, Katharina Kitzinger $\mathbb{D}^{2}$, David Kamanda Ngugi $^{3}$, Petra Büsing ${ }^{3}$, Sten Littmann ${ }^{2}$, Marcel M. M. Kuypers ${ }^{2}$, \\ Bernhard Schink ${ }^{1}$ and Michael Pester (iD ${ }^{1,3,4}$
}

(c) The Author(s) 2022

Deep oligotrophic lakes sustain large populations of the class Nitrososphaeria (Thaumarchaeota) in their hypolimnion. They are thought to be the key ammonia oxidizers in this habitat, but their impact on $\mathrm{N}$-cycling in lakes has rarely been quantified. We followed this archaeal population in one of Europe's largest lakes, Lake Constance, for two consecutive years using metagenomics and metatranscriptomics combined with stable isotope-based activity measurements. An abundant (8-39\% of picoplankton) and transcriptionally active archaeal ecotype dominated the nitrifying community. It represented a freshwater-specific species present in major inland water bodies, for which we propose the name "Candidatus Nitrosopumilus limneticus". Its biomass corresponded to $12 \%$ of carbon stored in phytoplankton over the year's cycle. $\mathrm{Ca}$. N. limneticus populations incorporated significantly more ammonium than most other microorganisms in the hypolimnion and were driving potential ammonia oxidation rates of $6.0 \pm 0.9$ $\mathrm{nmol} \mathrm{l}^{-1} \mathrm{~d}^{-1}$, corresponding to potential cell-specific rates of $0.21 \pm 0.11 \mathrm{fmol} \mathrm{cell}^{-1} \mathrm{~d}^{-1}$. At the ecosystem level, this translates to a maximum capacity of archaea-driven nitrification of $1.76 \times 10^{9} \mathrm{~g} \mathrm{~N}$-ammonia per year or $11 \%$ of N-biomass produced annually by phytoplankton. We show that ammonia-oxidizing archaea play an equally important role in the nitrogen cycle of deep oligotrophic lakes as their counterparts in marine ecosystems.

The ISME Journal (2022) 16:1647-1656; https://doi.org/10.1038/s41396-022-01216-9

\section{INTRODUCTION}

Freshwater lakes are important drinking water reservoirs. To be suitable as drinking water and to prevent toxicity to fish, ammonia must not accumulate. Nitrification prevents an accumulation of ammonia and converts it to nitrate via nitrite, with ammonia oxidation generally being the rate-limiting step [1]. Although nitrification does not directly change the inventory of inorganic $\mathrm{N}$ in freshwater ecosystems, it represents a critical link between mineralization of organic $\mathrm{N}$ and its eventual loss as $\mathrm{N}_{2}$ to the atmosphere through denitrification or anaerobic ammonium oxidation [1]. The process of ammonia oxidation is catalyzed by three different microbial guilds. Two of these, the ammoniaoxidizing archaea $(A O A)[2,3]$ and the ammonia-oxidizing bacteria (AOB) [4], oxidize ammonia to nitrite and depend on nitriteoxidizing bacteria (NOB) [5] to complete nitrification by further oxidizing nitrite to nitrate. The third guild oxidizes ammonia directly to nitrate and is therefore referred to as complete ammonia oxidizers (comammox) $[6,7]$.

In general, the ratio of $A O A$ to $A O B$ decreases with increasing trophic state of freshwater lakes, as $A O B$ have a preference for increased inorganic nitrogen loading and $A O A$ are sensitive to copper complexation by organic matter [8-14]. In contrast, comammox bacteria have been detected at very low abundances in lacustrine systems, if at all $[15,16]$. In snapshot analyses of oligotrophic lakes, AOA typically outnumbered $A O B$, especially in the deep oxygenated hypolimnion, and constituted up to $19 \%$ of the archaeal and bacterial picoplankton [10, 15, 17-20]. These observations resemble the situation in marine ecosystems, where AOA account for up to $40 \%$ of all microorganisms in the deep sea and thus are estimated to be among the most numerous microorganisms on Earth [21, 22]. In contrast to marine ecosystems, the impact of planktonic freshwater AOA on $\mathrm{N}$ cycling in oligotrophic lakes, which are often important drinking water reservoirs, is severely understudied and yet to be quantified.

Lake Constance is an oligotrophic, fully oxygenated lake that provides drinking water to more than five million people [23]. Being the second largest lake by volume in Central Europe, it represents an important model habitat for limnological processes [24]. A year-round survey of Lake Constance waters established that a single $16 \mathrm{~S}$ rRNA gene-ecotype of AOA, related to the genus Nitrosopumilus (class Nitrososphaeria, "Thaumarchaeota" [25]), constituted the largest nitrifier population along the depth profile throughout the year, with $A O B$ being two orders of magnitude less abundant [16]. At the same time, comammox bacteria were below the detection limit as based on diagnostic PCR of their amoA gene [16], which encodes the structural subunit of the key enzyme for ammonia oxidation, ammonia monooxygenase. Here, we link the predominant AOA population in this oligotrophic lake to ammonia oxidation activity and quantify this important ecosystem service at the single-cell, population, and ecosystem levels.

\footnotetext{
${ }^{1}$ Department of Biology, University of Konstanz, Universitätsstrasse 10, Konstanz D-78457, Germany. ${ }^{2}$ Max Planck Institute for Marine Microbiology, Celsiusstrasse 1, D-28359 Bremen, Germany. ${ }^{3}$ Leibniz Institute DSMZ - German Collection of Microorganisms and Cell Cultures GmbH, Inhoffenstr. 7B, D-38124 Braunschweig, Germany. ${ }^{4}$ Technical University of Braunschweig, Institute for Microbiology, Spielmannstrasse 7, D-38106 Braunschweig, Germany. ${ }^{\circledR}$ email: Michael.Pester@dsmz.de
}

Received: 23 August 2021 Revised: 16 February 2022 Accepted: 18 February 2022

Published online: 8 March 2022 


\section{MATERIAL AND METHODS}

\section{Study area and sampling procedure}

Lake Constance is a monomictic peri-alpine lake with a maximum depth of $251 \mathrm{~m}$. Sampling was conducted at the long-term ecological research station of the University of Konstanz $\left(47.75788^{\circ} \mathrm{N}, 9.12617^{\circ} \mathrm{E}\right)$, which is located in the northwestern branch of Upper Lake Constance with a maximum depth of around $140 \mathrm{~m}$. Upper Lake Constance is oligotrophic and has a permanently oxygenated hypolimnion throughout the year. In this study, we refer to Upper Lake Constance as "Lake Constance" excluding the smaller, shallow, and mesotrophic Lower Lake Constance. Measurements of environmental parameters followed standard procedures as detailed in the Supplementary Text.

For quantitative PCR, water was sampled from $85 \mathrm{~m}$ depth in three to four replicates $(2.5-5.0 \mathrm{l})$ on a monthly basis from November 2017 to November 2019 [21.11.2017, 19.12.2017; 09.01.2018, 06.02.2018, 13.03.2018, 24.04.2018, 22.05.2018, 19.06.2018, 17.07.2018, 14.08.2018, 11.09.2018, 23.10.2018. 18.12.2018, 11.01.2019, 13.02.2018, 24.04.2019, 18.06.2019, 03.07.2019, 25.09.2019, 05.11.2019, (dd.mm.yyyy)]. Nine of these samples taken in the period from November 2017 to December 2018 were used for metagenome analyses as well (detailed in Fig. 1d and Supplementary Table S1). Water was pre-filtered through a $70 \mu \mathrm{m}$ and 30 $\mu \mathrm{m}$ nylon mesh (Franz Eckert GmbH, Germany) to remove larger organisms and was filtered on board first through $5 \mu \mathrm{m}$ and then through $0.2 \mu \mathrm{m}$ polycarbonate filters ( $47 \mathrm{~mm}$, Merck, Darmstadt, Germany) using pressurized air. Filters were stored immediately on dry ice on board and at $-20^{\circ} \mathrm{C}$ in the laboratory until further processing.

Sampling for metatranscriptome analyses took place between November 2018 and November 2019 [07.11.2018, 13.02.2019, 24.04.2019, 03.07.2019, 25.09.2019, 05.11.2019 (dd.mm.yyyy)].Water was sampled in three replicates directly at the desired water depth of $85 \mathrm{~m}$ with a WTS-LV in-situ pump (McLane research laboratories, Inc., Massachusetts, USA). Within $1 \mathrm{~h}$ and depending on the biomass captured, 30.7-126.2 I of water (on average $67.2 \pm 27.8 \mathrm{I}$ ) were filtered. Water was passed serially through a $30 \mu \mathrm{m}$ mesh (Franz Eckert $\mathrm{GmbH}), 5 \mu \mathrm{m}$, and $0.22 \mu \mathrm{m}$ filters $(142 \mathrm{~mm}$, Merck) with the initial flow rate set to $3.51 \mathrm{~min}^{-1}$. Filters with $5 \mu \mathrm{m}$ and $0.22 \mu \mathrm{m}$ pore size were immediately placed on dry ice on board and stored at $-80^{\circ} \mathrm{C}$ in the laboratory until further processing. Sampling of the third replicate in February and April 2019 failed.

\section{Nucleic acid extraction, qPCR, and CARD-FISH analyses}

DNA and RNA were extracted separately from respective $0.22 \mu \mathrm{m}$ filters after a modified protocol designed previously [26] as detailed in the Supplementary Text. Quantitative PCR assays of total bacterial and archaeal $16 \mathrm{~S}$ rRNA genes as well as archaeal $a m o A$ were performed as described recently [16]. The $a m o A$ qPCR assay was specifically designed to target archaeal $a m o A$ retrieved from the water column of Lake Constance. The efficiency of qPCR assays targeting the archaeal $a m o A$ and the total bacterial and archaeal 16S rRNA genes were on average $72.5 \pm 4.0 \%$ and $91.3 \pm 1.6 \%$, respectively. After each run, qPCR specificity was checked with a melting curve. In addition, GPCR products from selected runs were visualized on a $2.5 \%$-agarose gel to verify the absence of unspecific PCR products. PCR-inhibitory substances were not evident by qPCR analyses of dilution series of two selected lake water DNA extracts.

For CARD-FISH analysis, $50 \mathrm{ml}$ of lake water was sampled after $48 \mathrm{~h}$ (November 5th, 2019) or $67 \mathrm{~h}$ (June 18th, 2019) of the ${ }^{15} \mathrm{~N}^{-\mathrm{NH}_{4}}{ }^{+}$incubation experiments described below and fixed overnight at $4^{\circ} \mathrm{C}$ with paraformaldehyde (final concentration 1\%, without methanol, Electron Microscopy Sciences, Hatfield, PA, USA). Cells were filtered onto $0.2 \mu \mathrm{m}$ polycarbonate filters (GTTP, Merck Millipore) and washed with filter-sterilized lake water. Filters were stored at $-20^{\circ} \mathrm{C}$ until analysis. Before CARD-FISH, cells on filter sections were immobilized by embedding in $0.1 \%$ low-gelling agarose (MetaPhor, Lonza, Rockland, ME, USA). CARD-FISH was performed using a HRP-labeled oligonucleotide probe specific for Nitrososphaeria/"Thaumarchaeota" (HRP-labeled Thaum726 [GCTTTCATCCCTCACCGTC] and unlabeled competitors [Thaum726_compA: GCTTTCGTCCCTCACCGTC, Thaum726_compB: GCTTTCATCCCTCACTGTC]) [27, 28]. Negative controls using probe NonEUB [ACTCCTACGGGAGGCAGC] [29] were performed according to a defined protocol [30] to exclude unspecific signals. Further CARDFISH analysis was done as described recently [31] and in the Supplementary Text.

\section{Metagenomics and metatranscriptomics}

Metagenome sequencing libraries were prepared with the NEBNext Ultra DNA Library Prep Kit for Illumina (New England Biolabs GmbH, Frankfurt am Main, Germany) and sequenced on a NextSeq500 sequencer (Illumina) using $2 \times 150$ bases. In addition, DNA from November 2017 was sequenced by PacBio sequencing on a Sequel instrument (Pacific Biosciences, Menlo Park, CA, USA) using circular consensus sequencing with a target length of 2 kilobases. Bioinformatics processing, genome binning, and phylogenetic analysis followed standard procedures as described in the Supplementary Text.

For metatranscriptome sequencing, messenger RNA (mRNA) was enriched from total RNA extracts by depleting ribosomal RNA with the Ribo-off rRNA Depletion Kit for bacteria (Vazyme, Nanjing, China). Thereafter, the sequencing library was prepared with the TruSeq Stranded mRNA Library Prep (Illumina) and sequenced on a NextSeq500 sequencer using $2 \times 150$ bases. Bioinformatics processing to determine the transcriptional levels of selected genes as well as network analysis of co-transcribed genes are detailed in the Supplementary Text.

\section{Potential ammonia oxidation rate measurements}

To determine potential ammonia oxidation and ammonium assimilation rates, ${ }^{15} \mathrm{~N}-\mathrm{NH}_{4}{ }^{+}$-tracer experiments were carried out as described recently [31]. Water was sampled from $85 \mathrm{~m}$ depth using a Niskin bottle on 18.06.2019, 29.07.2019, 28.08.2019, and 05.11.2019 (dd.mm.yyyy). Thereafter, 4.5 I were distributed on board to 5 -I glass bottles. Bottles were sealed with oxalic acid and sodium hydroxide cleaned butyl rubber stoppers and wrapped in aluminum foil to protect them from light. Within $1-7 \mathrm{~h}$ after sampling, ${ }^{15} \mathrm{~N}$-tracer experiments were started by addition of $\left({ }^{15} \mathrm{NH}_{4}\right)_{2} \mathrm{SO}_{4}\left(10 \mu \mathrm{M}\right.$ final ${ }^{15} \mathrm{~N}$-concentration) and bottles were incubated at in-situ temperature $\left(4^{\circ} \mathrm{C}\right)$ in the dark. All incubations were done in biological triplicates. Subsamples of $10 \mathrm{ml}$ were taken for potential ammonia oxidation rate measurements over a time period of $48 \mathrm{~h}(67 \mathrm{~h}$ in June), filter-sterilized $(0.2 \mu \mathrm{m})$ and frozen at $-20^{\circ} \mathrm{C} .{ }^{15} \mathrm{~N}$-ammonium labeling percentage was inferred in two steps: First, in-situ ammonium concentrations were determined using the spectrophotometric salicylate method [32]. Second, added ${ }^{15} \mathrm{~N}$-ammonium was measured in samples taken immediately after isotope addition by conversion to $\mathrm{N}_{2}$ using alkaline hypobromite as described previously [33]. The amount of added

${ }^{15} \mathrm{~N}$-ammonium was divided by the sum of in-situ ammonium and added

${ }^{15} \mathrm{~N}$-ammonium to determine the labeling percentage, which was $>99 \%$ for all samples. Thereafter, potential ammonia oxidation rates were determined from combined increase in ${ }^{15} \mathrm{~N}$-nitrite and ${ }^{15} \mathrm{~N}$-nitrate over time. First, ${ }^{15} \mathrm{~N}$-nitrite was measured by conversion to $\mathrm{N}_{2}$ with sulfamic acid [34], and the resulting ${ }^{29} \mathrm{~N}_{2}$ was measured by gas chromatography isotope ratio mass spectrometry (IRMS) using an Isoprime Trace Gas for cryogenic concentration of gases coupled to a sector field IsoPrime100 with a multicollector for simultaneous detection of multiple masses (Isoprime, Manchester, UK). After the ${ }^{15} \mathrm{~N}$-nitrite measurement, nitrate was reduced to nitrite using spongy cadmium and subsequently converted to $\mathrm{N}_{2}$ via sulfamic acid [34, 35]. To calculate potential ammonia oxidation rates, the sum of ${ }^{15} \mathrm{~N}$-nitrite and ${ }^{15} \mathrm{~N}$-nitrate was used to give the total ${ }^{15} \mathrm{NO}_{\mathrm{x}}$ production per time point. Rates were inferred from the slopes of linear regressions; only slopes that were significantly different from zero are reported $(P<0.05$, one-tailed $t$-distribution test).

\section{Single cell ${ }^{15} \mathrm{~N}$-uptake measurements from combined CARD- FISH nanoSIMS}

After $48 \mathrm{~h}$ of the ${ }^{15} \mathrm{~N}^{-\mathrm{NH}_{4}}{ }^{+}$-tracer incubation experiment in November 2019, water samples were taken for Nitrososphaeria-specific CARD-FISH and subsequent nanoscale secondary ion mass spectrometry (nanoSIMS) analyses [36]. A subsample of the incubated water $(50 \mathrm{ml})$ was fixed and used for CARD-FISH as described above, but without embedding filter sections in agarose. After CARD-FISH and DAPI staining, regions of interest (ROIs) were marked on a laser microdissection microscope (6000 B, Leica) and images of CARD-FISH signals were acquired on an epifluorescence microscope (Axio Imager, Zeiss). After image acquisition, the filters were sputtered with a $7 \mathrm{~nm}$ gold layer to create a conductive surface for nanoSIMS analyses. Single-cell ${ }^{15} \mathrm{~N}$-uptake from ${ }^{15} \mathrm{~N}$-ammonium was determined using a nanoSIMS 50 L (CAMECA), as previously described [37]. Instrument performance was monitored regularly on graphite planchet and on caffeine standards. Due to the small size of AOA $(<1$ $\mu \mathrm{m})$, samples were only briefly $(10-20 \mathrm{~s})$ pre-sputtered with a $\mathrm{Cs}^{+}$beam $(\sim 300 \mathrm{pA})$ before measurement. Measurements were performed on a field size of $10 \times 10 \mu \mathrm{m}$ to $15 \times 15 \mu \mathrm{m}$ with a dwelling time of $2 \mathrm{~ms}$ per pixel and a resolution of $256 \times 256$ pixels over $25-40$ planes. Analysis of the acquired data was performed using the Look@NanoSIMS software package [38]. The potential growth and $\mathrm{N}$-assimilation rates of single cells were 

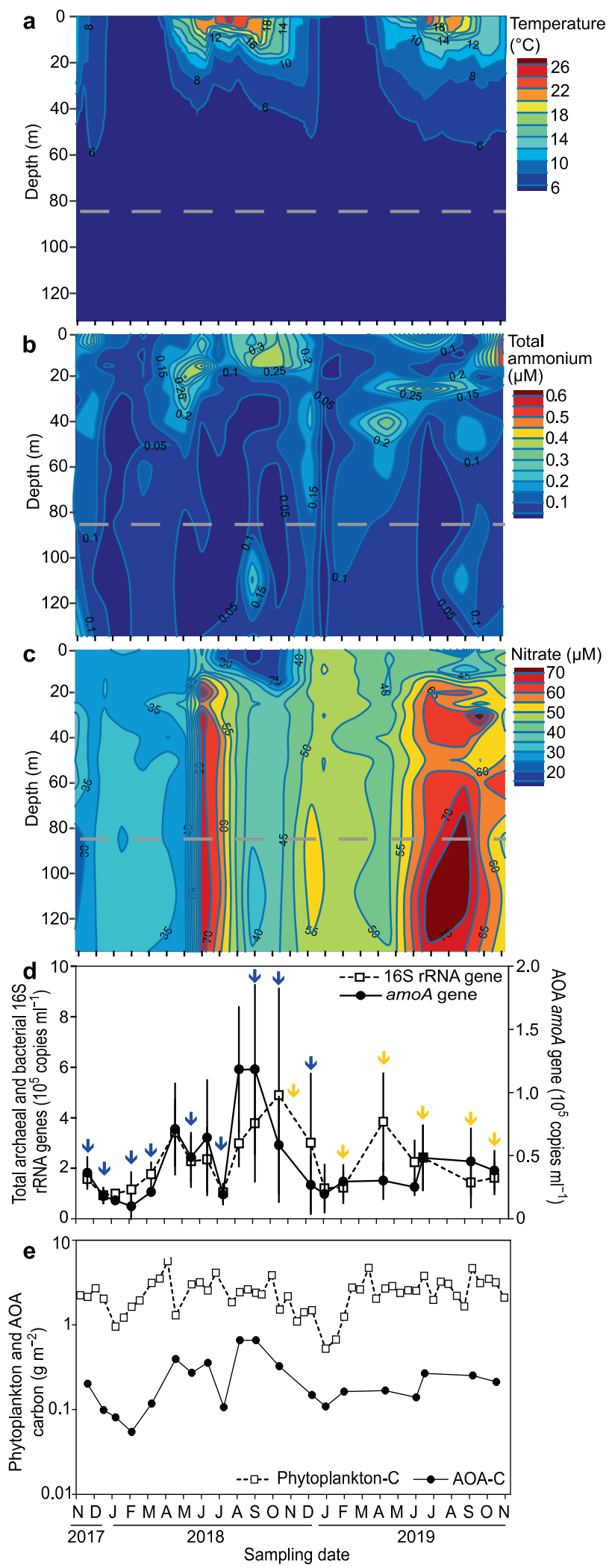

calculated as described recently [39]. We did not account for a possible ${ }^{15} \mathrm{~N}$-isotope dilution effect introduced by CARD-FISH [40-42], as the strength of the effect depends on the growth phase, activity, and type of cells, which vary strongly in environmental samples. Therefore, the reported potential single cell growth and ammonium assimilation rates are a conservative estimate.
Fig. 1 Temporal dynamics of the AOA population in relation to environmental parameters as well as the pico- and phytoplankton. Seasonality of physico-chemical parameters $(\mathbf{a}-\mathbf{c})$, the total archaeal and bacterial picoplankton as well as the AOA population at $85 \mathrm{~m}$ depth (d), and the carbon budget of the phytoplankton and AOA population (e) over two consecutive years in the water column of Lake Constance. Please note that the carbon budget values are shown on a logarithmic scale. The sampling depth for qPCR, metagenome and metatranscriptome analyses is indicated as a dashed gray line at $85 \mathrm{~m}$. Arrows indicate time points for metagenome (blue) and metatranscriptome (yellow) sampling. qPCR analyses were done in replicates of 3 or 4 , except for December $18^{\text {th }}$, 2018, where only duplicates could be measured for the AOA amoA.

\section{AOA carbon content calculations}

The carbon content of individual AOA cells was inferred according to the nonlinear relationship between carbon mass and cell volume (Eq. 1) as recently established by Khachikyan et al. [43]:

$m_{\text {carbon }}=197 \times V^{0.46}$

with $m_{\text {carbon }}$ being the mass of carbon in femtograms and $V$ being the volume in cubic micrometers of an average AOA cell. $V$ was calculated assuming a prolate spheroid cell shape according to Eq. 2 as laid out before [44]:

$V=\frac{\pi}{6} \times W^{2} \times L$,

with $W$ being the width and $L$ being the length of the cells. AOA cell dimensions were directly obtained from the nanoSIMS measurements, which, unlike fluorescent signals, do not overestimate cell size due to the fluorescence "halo-effect". The volumetric carbon content of the AOA population was calculated for each time point of our archaeal amoA qPCR survey (Fig. 1d) by multiplying the mean carbon content of a single Nitrosopumilus-AOA cell $\left(m_{\text {carbon }}\right)$ with the total abundance of AOA $\left(A_{q P C R}\right)$ as inferred by archaeal $a m o A$ qPCR:

volumetric $C$ content $(\mathrm{AOA})=m_{\text {carbon }} \times A_{q P C R}$

This volumetric $C$ content was integrated over the water column of the hypolimnion and compared to the depth-integrated $C$ content of the phytoplankton, which was inferred from depth-resolved chlorophyll $a$ concentrations using the $\mathrm{C}$ : $\mathrm{Chl} a$ (weight:weight) conversion factor of 31.5 [45].

\section{AOA nitrogen flux calculations}

Potential cell-specific ammonia oxidation rates of the AOA population $\left(R_{\text {cell- }}\right.$ specific $)$ were inferred by dividing potential ammonia oxidation rates $\left(R_{\text {pot }}\right)$ by the total abundance of AOA as inferred by archaeal amoA qPCR $\left(A_{q P C R}\right)$ obtained at the same time points:

$R_{\text {cell-specific }}=\frac{R_{\text {pot }}}{A_{q P C R}}$

The mean of potential cell-specific ammonia oxidation rates was used to infer the annual volumetric ammonia oxidation rate of the AOA population ( $\left.R_{\text {annual }}\right)$ by integrating over our complete data set of total $\mathrm{AOA}$ abundances in the years 2017 to 2019 :

$R_{\text {annual }}=\frac{\sum_{1}^{n}\left[\left(\bar{R}_{\text {cell-specific }} \frac{A_{q P C R, n}+A_{q P C R, n-1}}{2}\right)\left(t_{n}-t_{n-1}\right)\right]}{\text { years }}$

Whenever average values were used to calculate the mean, e.g., to estimate mean ammonia oxidation rates over the year, the propagation of uncertainty was calculated and the resulting uncertainty provided next to the mean.

\section{RESULTS \& DISCUSSION}

AOA account for $8-39 \%$ of total archaea and bacteria in the hypolimnion

Depth profiles of total ammonium $\left(\mathrm{NH}_{4}^{+}+\mathrm{NH}_{3}\right)$ and nitrate showed typical inverse concentration profiles during periods of 
primary productivity (Fig. 1a-c). Total ammonium decreased and nitrate increased towards the hypolimnion, indicative of active ammonium consumption and nitrate production in hypolimnetic waters, presumably by nitrification (Fig. $1 \mathrm{~b}, \mathrm{c}$ ). Hence, we decided to follow annual dynamics of the AOA population in the central part of the hypolimnion at $85 \mathrm{~m}$ depth. Copy numbers of Lake Constance-specific archaeal amoA genes were determined by quantitative PCR (qPCR). As $a m o A$ is typically present as a single copy gene in AOA [46], amoA copy numbers were compared to total archaeal and bacterial 16S rRNA gene copy numbers to estimate AOA relative abundance. This confirmed the presence of a large prevailing $A O A$ population in the hypolimnion ranging from $8.0 \pm 0.9 \%$ to $38.9 \pm 5.7 \%$ of the archaeal and bacterial picoplankton. Absolute abundances ranged between $9.8 \times 10^{3} \pm$ $1.0 \times 10^{4}$ and $1.2 \times 10^{5} \pm 4.9 \times 10^{4}$ amoA copies $\mathrm{ml}^{-1}$ in winter and summer, respectively, with a mean copy number of $4.3 \times 10^{4}$ amoA copies $\mathrm{ml}^{-1}$ (Fig. 1d). These qPCR results corresponded well to direct Nitrososphaeria cell counts based on catalyzed reporter deposition fluorescence in-situ hybridization (CARD-FISH) at two selected time points (Supplementary Fig. S1). Therefore, we use the terms AOA and Nitrososphaeria as synonyms from here on.

\section{A freshwater-specific AOA species dominates the nitrifier community}

To gain insight into the genetic repertoire of the $A O A$, we conducted a metagenomic survey of hypolimnetic waters covering nine time points from November 2017 to December 2018 (Fig. 1d). Best assembly results were obtained by a co-assembly of the winter datasets November 2017, December 2017 and February 2018 , which resulted in a single metagenome-assembled genome (MAG) related to Nitrososphaeria that was further refined by long PacBio reads for scaffolding. This resulted in a high quality assembly of eight contigs spanning $1.2 \mathrm{Mbp}$, with a checkMestimated [47] coverage of $99 \%$ and contamination of $0 \%$ (Supplementary Table S1). The 16S rRNA gene of MAG AOA-LC4 was $100 \%$ identical to the single $16 \mathrm{~S}$ rRNA gene-ecotype that was previously shown in an amplicon-based study to outnumber all other $\mathrm{AOA}, \mathrm{AOB}$, and comammox populations by at least two orders of magnitude throughout the depth profile of Lake Constance [16] and thus represents the main ammonia oxidizer of this lake. An index of replication (iREP) [48] analysis indicated active replication of the AOA-LC4 population throughout the entire year with a mean of $50 \pm 19 \%$ and ranging from a minimum of $34 \%$ in November/December 2017 to a maximum of $90 \%$ in October 2018 (Supplementary Table S1). Although the iRep algorithm was recently questioned to work with population genomes integrating over many co-occurring but heterogeneous close relatives [49], it performs well for uniform population genomes such as pure cultures [48, 50, 51]. We consider the extremely low and highly skewed AOA diversity in Lake Constance [16] to be rather representative of the latter case. The phylogenomic analysis placed AOA-LC4 within a freshwater/ brackish water-associated clade of the Nitrosopumilaceae, which was distinct from marine representatives (Fig. 2). The closest relatives were MAGs retrieved from Lake Baikal (G182) and from the Caspian Sea (Casp-thauma1), which, together with AOA-LC4, represent a new species within the genus Nitrosopumilus based on genome-wide average nucleotide and amino acid identities (Supplementary Fig. S2). Therefore, AOA-LC4 is a representative of AOA in major inland water bodies.

AOA-LC4 encoded the core genetic repertoire of Nitrosopumilus species $[52,53]$. This included all genes necessary for oxidation of ammonia to hydroxylamine in the canonical arrangement $\operatorname{amoBCxA}$, as well as genes with a proposed function in further oxidation of hydroxylamine to nitrite, i.e., genes encoding (putative) multicopper oxidases including a postulated reversely operating nitrite reductase ("nirK") [54, 55]. In addition, AOA-LC4 carries genes for a urea transporter (dur3), urea amidohydrolase

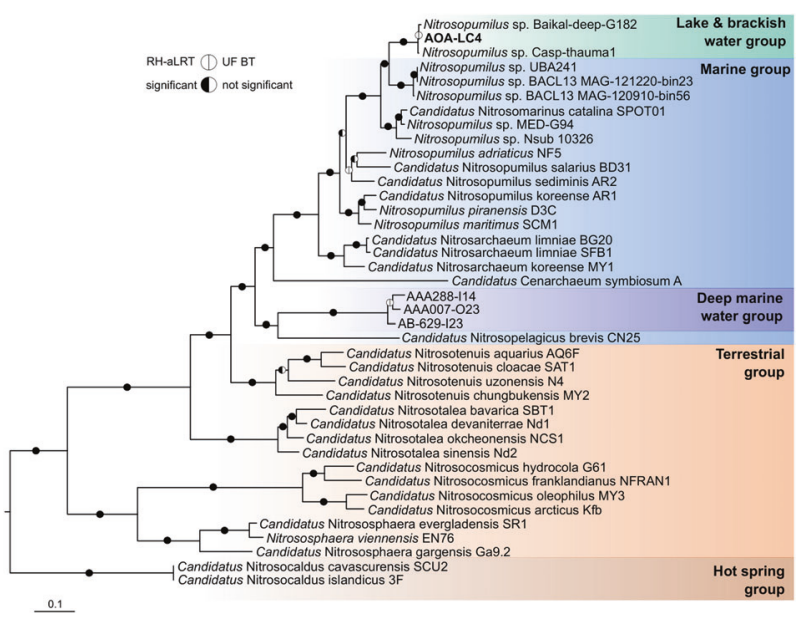

Fig. 2 Phylogeny of MAG AOA-LC4 in relation to MAGs retrieved from other major inland water bodies and major lineages within the class Nitrososphaeria. The phylogenomic maximum likelihood tree was re-constructed using the IQ-tree algorithm [89] on the basis of a concatenated amino acid alignment of 122 translated singlecopy genes that were established by the GTDB-based taxonomy for phylogenetic inference of archaea [25]. Branch support was tested with the Shimodaira-Hasegawa approximate likelihood-ratio test (SH-aLRT; 1000 replicates) and ultrafast bootstrap (1000 replicates) using the IQ-tree software package [89]. Branch support was set as significant at $\geq 80 \%$ for $\mathrm{SH}$-aLRT and $\geq 95 \%$ for ultrafast bootstrap values (black semi-circles for significant and white for nonsignificant). Non-AOA "Thaumarchaeota" archaeon sp. BS3 (IMG Taxon ID 2721755844), unclassified "Thaumarchaeota" DRTY-7 bin 36 (2263082001), and "Thaumarchaeota" archaeon strain DS1 (2263082000) were used as outgroup. The scale bar indicates $10 \%$ estimated amino acid sequence divergence. Accession numbers or respective Taxon IDs can be found in Supplementary Table S3.

(ure $A B C$ ), and urease accessory proteins (ureDEFGH). Furthermore, it is prototrophic for the vitamins thiamine (B1), riboflavin (B2), biotin (B7), and cobalamin (B12). For carbon fixation, it encodes the energy-efficient variant of the 3-hydroxypropionyl/4-hydroxybutyryl pathway (Supplementary Table S2).

To obtain a complete picture of the nitrifying community, we screened all obtained MAGs and single contigs for the presence of $a m o A$ as indicator for all ammonia oxidizers, nxrB (encoding the beta subunit of nitrite oxidoreductase) as indicator for all nitrite - oxidizing bacteria [56], or both genes in the same MAG/contig as indicator for comammox bacteria [5]. MAG AOB-LC263 encoded the bacterial $a m o A B$ genes and was affiliated with a novel genus within the Nitrosomonadaceae (Proteobacteria) (Supplementary Text and Supplementary Fig. S3, S4). In addition, we found two contigs (AOB-LC199628 and AOB-LC368213), which encoded either $a m o A B$ or $a m o C A B$ and were again related to the Nitrosomonadaceae (Supplementary Fig. S5). However, both contigs did not group into any of the binned MAGs that fulfilled our completeness criteria (>50\%). Two MAGs, NOB-LC32 and NOBLC29, encoded $n \times r A B$ and $n x r B$, respectively, and were related to Nitrospira lineage II (Nitrospirae) (Supplementary Text and Supplementary Figs. S6-8). Interestingly, we recovered a third Nitrospira lineage II MAG, COM-LC224 (Fig. S6), which encoded both $a m o A$ and $n x r B$ (Supplementary Fig. S8, S9). Closer inspection identified the full set of $a m o C A B$, hao, and $n x r A B$ encoding the ammonia monooxygenase, hydroxylamine reductase, and nitrite oxidoreductase, respectively. This finding was further supported by the affiliation of MAG COM-LC224 to comammox clade B as inferred by independent phylogenetic analysis of its concatenated single copy marker genes as well as its functional marker genes amoA and $n x r B$ (Supplementary Text and Supplementary Fig. S6, S8, S9). Throughout the year, MAGs AOB-LC263 and COM-LC224 as 
well as the contigs AOB-LC199628 and AOB-LC368213 were 1-2 orders of magnitude less abundant than AOA-LC4 as inferred from mapping coverage results in the nine metagenomes (Supplementary Table S1). Similarly, MAGs NOB-LC32 and NOB-LC29 were on average one order of magnitude less abundant than AOA-LC4 with the exception of February and October 2018 where they were equally abundant (Supplementary Table S1). This is consistent with results obtained 3 years earlier by $16 \mathrm{~S}$ rRNA gene amplicon sequencing and $a m o A$ screening [16].

Based on the low total ammonium concentrations in Lake Constance (on average $0.07 \pm 0.04 \mu \mathrm{M}$ at $85 \mathrm{~m}$ depth, Fig. 1) and both the higher substrate affinities $\left(\mathrm{K}_{\mathrm{m}}\right.$-apparent) and higher specific substrate affinities $\left(a^{\circ}\right)$ for total ammonium of cultivated Nitrosopumilus-AOA compared to $A O B$, it was not surprising that AOA-LC4 dominated over all detected $A O B$ (although planktonic freshwater $A O B$ have not been characterized for their kinetic properties yet). However, based on the overlapping $\mathrm{K}_{\mathrm{m}}$-apparent and $\mathrm{a}^{\circ}$-values of Nitrosopumilus-AOA and comammox-Nitrospira, one may have expected a more abundant comammox population $[57,58]$. A possible explanation could be that comammox are hypothesized to be typical K-strategists being rather adapted to slow growth but higher yield as based on the theory of optimal pathway length [59]. Indeed, the comammox Nitrospira inopinata was shown to achieve higher growth yields per mole ammonia at the drawback of lower maximum ammonia oxidation rates as compared to AOAs [57]. These slow growth and metabolic rates of comammox in comparison to the high turnover rate of bacterioplankton biomass in general in the open water column of Lake Constance (1-13 days in the hypolimnion [60]) indicate that comammox-Nitrospira were likely outgrown by Nitrosopumilus-AOA.

\section{AOA-LC4 is transcriptionally active throughout the year}

The dominance of AOA-LC4 was also evident at the transcriptional level. In a metatranscriptome survey covering six time points from November 2018 to November 2019, amoA transcription of the AOA-LC4 population was consistently at least two orders of magnitude higher than that of the individual AOB-LC263, AOBLC199628, AOB-LC368213, or COM-LC224 populations (Fig. 3). Compared to the $n \times r B$ transcription of the NOB-LC32 and NOBLC29 populations, the amoA transcription of AOA-LC4 was consistently one order of magnitude higher, reflecting the relative abundance estimates based on normalized metagenomic coverage (Supplementary Table S1) and 16S rRNA gene amplicons [16]. Interestingly, the transcription of the COM-LC224 amoA gene was one order of magnitude lower than of its $n \times r B$, suggesting that nitrite oxidation may predominate over complete ammonia oxidation to nitrate in this microorganism, potentially driven by a shift from a K- to an r-strategy as outlined above. Alternatively, the represented two enzymes have different turnover times or regulation mechanisms.

Detailed analysis of the seasonally resolved AOA-LC4 population transcriptome identified $a m o A B C$ among the top ten transcribed genes at a steady level with little variation throughout the yearly cycle (Fig. 4, Supplementary Table S2). Transcription of amoABC was highly correlated $\left(r_{S} \geq 0.8\right)$ to each other and to transcription of "nirK" and a gene encoding a membrane-anchored PEFGCTERM domain-containing multicopper oxidase (locus JW390_30004) (Supplementary Fig. S10). The latter two were previously postulated to be involved in the yet unresolved archaeal pathway of ammonia oxidation to nitrite [53-55, 61]. On average, $a m o A B C$ showed a 16 to 119 fold higher transcription than the highest transcribed genes encoding either proteins of the large $(r p / 12, r p / 21 e)$ or small ribosomal subunit (rps11, rps15), which we used as reference housekeeping genes (Fig. 4). Also amt and $c d v B$, encoding a high-affinity ammonium transporter and the putative cell division protein B2, respectively, were consistently found among the top ten highest transcribed genes. Since the active center of the archaeal ammonia monooxygenase is

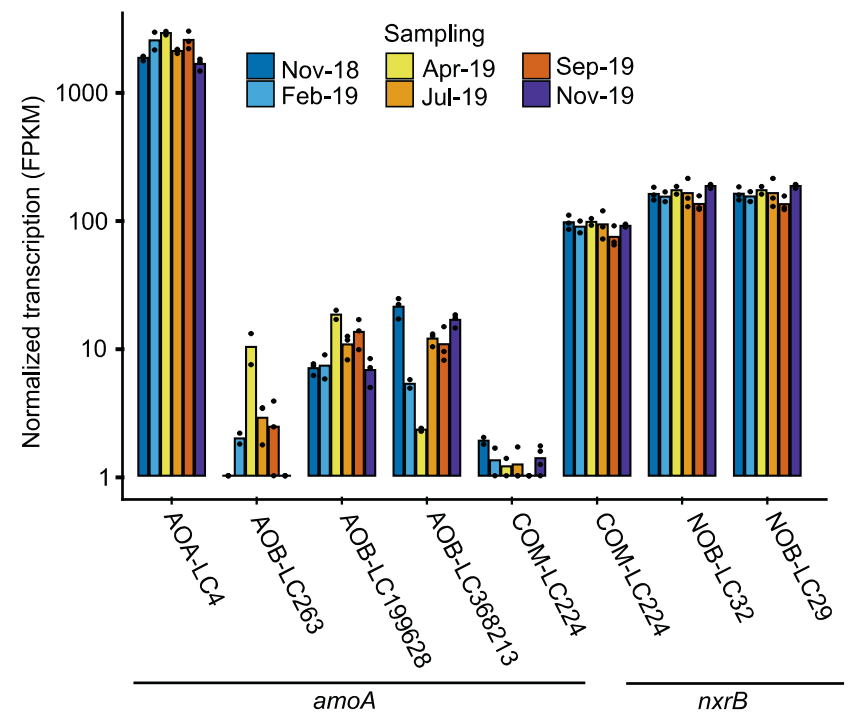

Fig. 3 Year-round transcriptional activity of the nitrifying community in the hypolimnion ( $85 \mathrm{~m}$ depth) of Lake Constance based on metatranscriptomics. Transcription of $a m o A$ (encoding ammonia monooxygenase subunit $A$ ) as functional marker for all ammonia oxidizers, $n \times r B$ (encoding nitrite oxidoreductase subunit B) as functional marker for all nitrite oxidizers, or both genes in the same MAG as indicator for comammox bacteria is shown across all identified nitrifying microorganisms. Bars represent the mean of three replicates, except for the February and April samples, where only two replicates could by analyzed. Individual replicates are indicated by single dots. FPKM values below 1 were set to 1 for a better representation on a $\log _{10}$-scale. FPKM, fragments per kilobase of transcripts per million mapped reads.

postulated to face the outside of the cytoplasmic membrane [55], the high transcriptional levels of amt imply that ammonia was transported into the cell for ammonium assimilation, most likely for further biomass production as evidenced by the high transcriptional levels of $c d v B$. This is in line with the consistent transcription of genes encoding the 3-hydroxypropionate/4hydroxybutyrate pathway for $\mathrm{CO}_{2}$ fixation, however, at 1 to 300 fold lower transcriptional levels as compared to the selected ribosomal reference genes (Fig. 4, Supplementary Table S2). Together, this resembles (meta-)transcriptomic data of actively growing AOA species in culture and in open marine waters with AOA-driven ammonia oxidation activity [54]. Therefore, we conclude that the AOA-LC4 population was actively oxidizing ammonia throughout the year. In contrast, genes associated with urea utilization were much less transcribed. While dur3 (encoding an urea transporter) was transcribed similar to the four highest transcribed ribosomal protein genes, ure $A B C$ (encoding urease) showed a 12 to 988 fold lower transcription. The same was true for ureDEFGH (encoding [putative] urease accessory proteins) with transcriptional levels either below the detection limit, or 43 to 1507 fold lower. However, low transcription of urease and ureaseassociated genes has previously been shown to be a poor predictor for lack of urea-based ammonia oxidation of AOA [54].

AOA predominate ammonium assimilation in the hypolimnion To link transcriptional to metabolic activity, we performed shortterm $(48 \mathrm{~h}){ }^{15} \mathrm{NH}_{4}{ }^{+}$-labeling experiments in parallel to our metatranscriptomic survey in November 2019. As described above, transcriptional activity of the AOA-LC4 population in these samples was high and exceeded other ammonia oxidizers' transcriptional levels (Fig. 3). As a measure of metabolic activity, incorporation of ${ }^{15} \mathrm{~N}$-ammonium was analyzed at the singlecell level using nanoscale secondary ion mass spectrometry (nanoSIMS) coupled to CARD-FISH identification of AOA cells. 


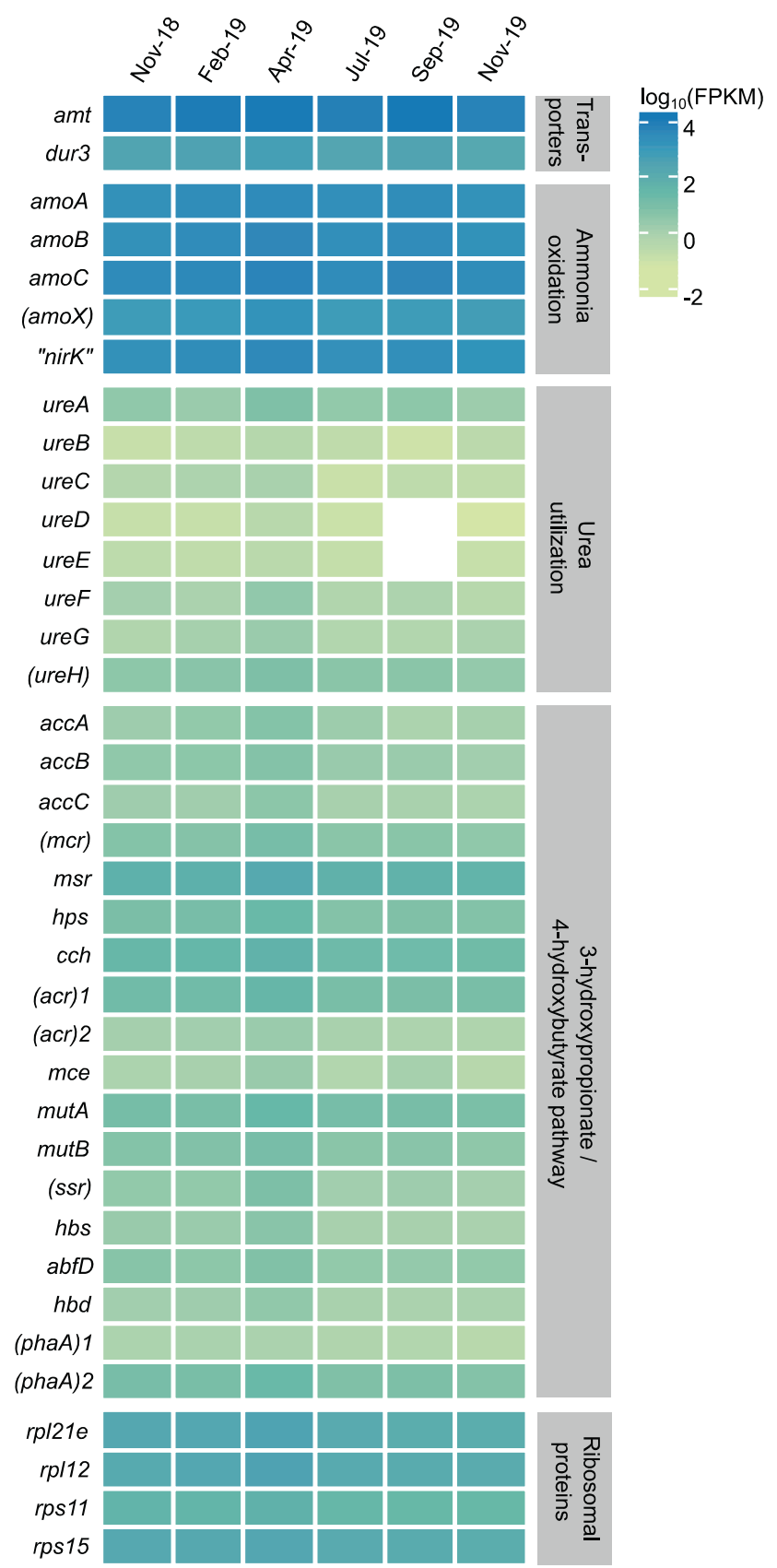

Fig. 4 Seasonally resolved transcription of genes involved in the nitrogen and carbon metabolism of AOA-LC4 at $85 \mathrm{~m}$ depth. As reference housekeeping genes, the two highest transcribed genes encoding either proteins of the large $(r p / 12, r p / 21 e)$ or small ribosomal subunit (rps11, rps15) are shown at the bottom. Transcription values are represented as $\log _{10}$-transformed mean FPKM (fragments per kilobase of transcripts per million mapped reads) values for every time point. Values represent the mean of three replicates, except for the February and April samples, where only two replicates could by analyzed. No transcription of a specific gene is indicated in white. Putatively annotated genes are given in brackets; gene duplicates were consecutively numbered.

All measured AOA cells ( $n_{\text {cells }}=37$ ) were metabolically active and incorporated ammonium at an average potential rate of $5.04 \pm$ $3.01 \mathrm{amol} \mathrm{NH}_{4}^{+}$cell $^{-1} \mathrm{~d}^{-1}$. The AOA population was significantly more enriched in ${ }^{15} \mathrm{~N}$ than the remaining picoplankton community $\left(n_{\text {cells }}=105\right.$, non-parametric Mann-Whitney $U$-test, $p<0.005$ ) (Fig. 5). This was in line with a cross-comparison of transcript levels of ammonia transporters detected across all metagenomes. Also here, $95-98 \%$ of all transcripts (mean 97\%) were attributed to $a m t$ of AOA-LC4. In addition, AOA-LC4 dominated the transcript levels of all detected urea transporter genes (mean $74 \%$, range $61-83 \%$ ) (Supplementary Table S2).

Using the nanoSIMS results, we calculated potential single-cell $\mathrm{N}$-based growth rates of $0.012 \pm 0.006 \mathrm{~d}^{-1}$ for AOA at the in-situ temperature of $4^{\circ} \mathrm{C}$. These rates are one order of magnitude lower than those previously observed in pure cultures of Nitrosopumilus maritimus [3] or for AOA in marine subtropical waters [31]. This can be explained by the higher incubation temperature of $28^{\circ} \mathrm{C}$ in the latter two studies. It should, however, be noted that two other studies in cold marine waters (ice-water to $4^{\circ} \mathrm{C}$ ) $[62,63]$ reported AOA growth rates comparable to those of $N$. maritimus at $28^{\circ} \mathrm{C}$ [3]. The nanoSIMS measurements were also used to quantify single AOA cell dimensions. The average AOA cell in Lake Constance is around $0.54 \pm 0.11 \mu \mathrm{m}$ long and $0.39 \pm 0.10 \mu \mathrm{m}$ wide and has a volume of $0.048 \pm 0.035 \mu \mathrm{m}^{3}$. Several methods have been used in the literature to estimate cellular C-content [63-66]. Here, we use the empirical relationship between cell volume and C-content established by Khachikyan et al. [43] across different microbial species, which directly determined cell mass on the single cell level [67]. Using this established empirical relationship between cell volume and cellular C-content, the average Lake Constance AOA cell has a C-content of $46 \pm 15 \mathrm{fg}^{-C}$ cell $^{-1}$. This cellular C-content is higher than that of marine and cultivated Nitrosopumilus strains (8-17 fg-C cell ${ }^{-1}[63-66]$. However, this is not unexpected given the 4.4-fold larger volume of Lake Constance AOA compared to, e.g., N. maritimus [43]. Integration of the inferred cellular C-content over the total abundance of Lake Constance AOA (Fig. 1d) results in $0.5-5.5 \mathrm{mg}^{-C} \mathrm{~m}^{-3}$ (mean 2.0 $\mathrm{mg}-\mathrm{C} \mathrm{m}^{-3}$ ) stored in AOA cells in the hypolimnion. Compared to phytoplankton biomass, which we inferred from depth-integrated chlorophyll $a$ measurements, and considering that the hypolimnion extends over $120 \mathrm{~m}$ at our sampling station, this AOA-stored carbon makes up 3.3-30.6\% (average 12.3\%) of carbon stored in phytoplankton over the year's cycle (Fig. 1e).

\section{AOA oxidize up to 1763 metric tons of ammonium-N per year in Lake Constance}

All independent lines of evidence obtained in this study arrived at the conclusion that the AOA-LC4 population is driving ammonia oxidation in Lake Constance, with a negligible contribution by $\mathrm{AOB}$ and comammox bacteria. This natural setting posed the unique opportunity to quantify the ecosystem function exerted by planktonic AOA and to link this information to a single ecotype. We followed potential ammonia oxidation rates in the hypolimnion (85 m depth) by ${ }^{15} \mathrm{NH}_{4}{ }^{+}$incubations over four independent time points from June to November 2019. Potential ammonia oxidation rates were very similar within this time period with an average of $6.0 \pm 0.9 \mathrm{nmol} \mathrm{I}^{-1} \mathrm{~d}^{-1}$ (Table 1). Although the obtained rates are potential rates, the absence of an obvious activity lag phase and the linearity of the activities $\left(R^{2}=0.91-1.00\right)$ throughout the incubation time $(48 \mathrm{~h})$ point towards an active AOA-LC4 population in situ (Supplementary Fig. S11). The elevated total ammonia concentrations $(10 \mu \mathrm{M})$ used to measure ammonia oxidation rates are in a range in which the maximum reaction rate of Nitrosopumilus species can be expected [58]. Our previously published estimate of the nitrification rate in Lake Constance was considerably higher but was based on ${ }^{15} \mathrm{~N}$-dilution from the nitrate pool [16] instead of measuring direct conversion of ${ }^{15} \mathrm{~N}$-ammonium to ${ }^{15} \mathrm{~N}$-nitrite/nitrate (this study). In addition, the previous single time point estimate was based on a high variation of residual ${ }^{15} \mathrm{~N}$ across replicates. Therefore, we consider the replicated potential rate measurements presented in this study to be more reliable. In addition, comparison to rates obtained from other oligotrophic and deep lakes such as Lake Superior, USA $[19,68]$, or Lake Taupo, New Zealand [69], showed that the 

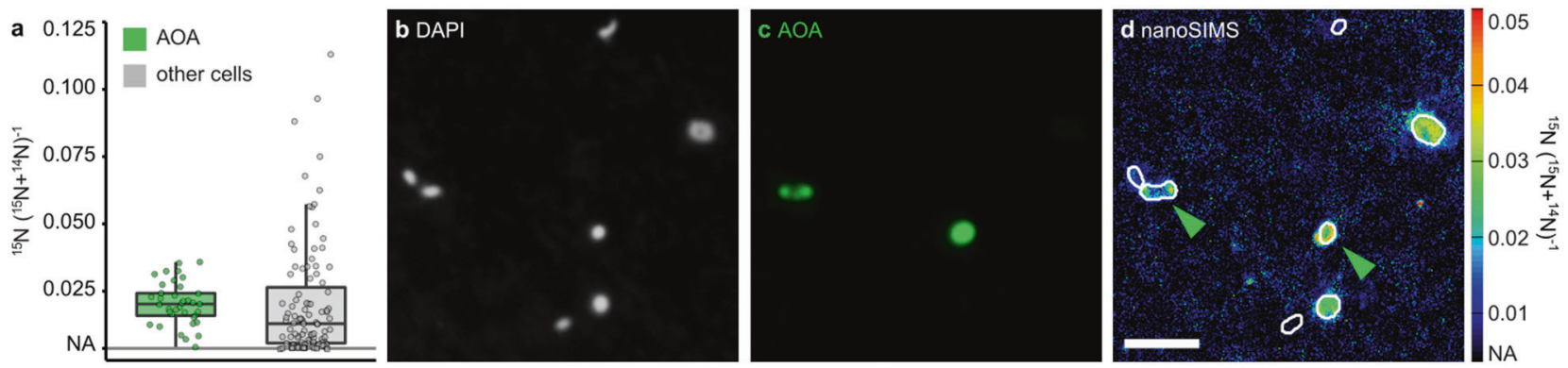

Fig. 5 Single-cell ammonium uptake by AOA and non-target picoplankton cells in hypolimnetic water from $85 \mathrm{~m}$ depth determined by nanoSIMS combined with CARD-FISH analysis. (a) ${ }^{15} \mathrm{~N}$ - enrichment of AOA $(n=37)$ and non-target cells $(n=105)$ after addition of ${ }^{15} \mathrm{~N}$-ammonium. Representative images of (b) DAPI-stained cells, (c) corresponding CARD-FISH signals with a Nitrososphaeria-specific probe, and (d) the corresponding ${ }^{15} \mathrm{~N}$-enrichment determined by nanoSIMS; green arrows indicate AOA; NA Natural abundance; scale bar = $2 \mu \mathrm{m}$.

Table 1. Potential ammonia oxidation rates $(n=3)$ and derived potential cell-specific AOA-driven ammonia oxidation rates in the hypolimnion of Lake Constance.

\begin{tabular}{|c|c|c|c|}
\hline $\begin{array}{l}\text { Sampling date (yyyy- } \\
\text { mm-dd) }\end{array}$ & $\begin{array}{l}\text { Potential ammonia oxidation rate in the } \\
\text { hypolimnion }\left(\mathrm{nmol} \mathrm{I}^{-1} \mathrm{~d}^{-1}\right)\end{array}$ & $\begin{array}{l}\text { archaeal amo } A \text { copy } \\
\text { numbers }\left(10^{4} \text { copies } \mathrm{ml}^{-1}\right)\end{array}$ & $\begin{array}{l}\text { Potential cell-specific ammonia } \\
\text { oxidation rate }\left(\mathrm{fmol} \text { cell }^{-1} \mathbf{d}^{-1}\right)\end{array}$ \\
\hline $2019-07-29$ & $4.61 \pm 0.39$ & n.d. & - \\
\hline $2019-11-05$ & $7.72 \pm 0.66$ & $3.81 \pm 1.55$ & $0.20 \pm 0.08$ \\
\hline
\end{tabular}

n.d. Not determined

Cell-specific ammonia oxidation rates were inferred from bulk ammonia oxidation rates divided by the respective absolute abundance of AOA measured by archaeal $a m o A$ qPCR.

obtained rates in Lake Constance were in the same range. The same was true when our data were compared to oligotrophic marine environments dominated by $\mathrm{AOA}$, where similar rates were observed in oligotrophic regions of the Atlantic Ocean [70, 71] and one order of magnitude lower rates in the oligotrophic equatorial Pacific Ocean [72, 73]. In contrast, volume-based ammonia oxidation rates in considerably smaller lakes with higher trophic status and higher total ammonium availabilities can be 1-5 orders of magnitude greater than those observed in large oligotrophic water bodies such as the hypolimnion of Lake Constance [74-77].

Measured potential rates in Lake Constance were normalized by archaeal amoA copy numbers for the June and November samples to determine potential cell-specific ammonia oxidation rates of the AOA population. At both time points, potential cell-specific rates were highly similar and averaged to $0.21 \pm 0.11 \mathrm{fmol} \mathrm{cell}^{-1}$ $\mathrm{d}^{-1}$ (Table 1). Like the calculated AOA growth rates, these cellspecific ammonia oxidation rates at $4^{\circ} \mathrm{C}$ are one order of magnitude lower than those observed for cultivated marine Nitrosopumilus species at 22 to $28^{\circ} \mathrm{C}[3,78]$, or for AOA in marine subtropical waters [39], as would be expected from the $Q_{10}$ temperature coefficient rule [79]. We used the obtained potential cell-specific rates to infer the upper limit of AOA-driven nitrification over our complete data set of AOA abundances in Lake Constance (Fig. 1d). As a result, we estimate that about $46 \mathrm{mg}$ $\mathrm{NH}_{4}^{+} \mathrm{m}^{-3} \mathrm{y}^{-1}$ can be oxidized by the AOA population. This translates to a total of $1.76 \times 10^{9} \mathrm{~g}\left(1763\right.$ metric tons) $\mathrm{N}^{-\mathrm{NH}_{4}}{ }^{+}$that can be oxidized per year if integrated over the whole lake's hypolimnion $\left(38.1 \mathrm{~km}^{3}\right)$. Since we cannot rule out local maxima of ammonia oxidation along the water column, e.g., due to temperature and total ammonium gradients during summer stratification, and given that we obtained the rates from water sampled at the center of the hypolimnion and at ca. $4^{\circ} \mathrm{C}$, the maximum capacity for AOA-driven ammonia oxidation might be even higher. In comparison, $15.7 \times 10^{9} \mathrm{~g}$ of biomass- $\mathrm{N}$ are annually produced by primary production in the photic zone of Lake Constance, when considering the annual primary productivity rate of $220 \mathrm{~g} \mathrm{C} \mathrm{m}^{-2} \mathrm{y}^{-1}$ [80], $473 \mathrm{~km}^{2}$ surface area of Lake Constance [24] and the Redfield ratio ( $C: N=106: 16)$. This results in potential AOA-converted $\mathrm{N}$ corresponding to $11 \%$ of photosynthetic biomass- $\mathrm{N}$ produced in the photic zone of Lake Constance. AOA-driven ammonia oxidation results eventually in the formation of nitrate. In addition, $13.7 \times 10^{9} \mathrm{~g}$ dissolved $\mathrm{N}$ (mainly in the form of nitrate) enter Lake Constance annually via riverine input, treated outflow of wastewater treatment plants, rain, and diffusive transport [81]. As such, nitrification contributes an upper limit of roughly $4 \%$ of the nitrate entering the nitrate pool annually $\left(42.8 \times 10^{9} \mathrm{~g} \mathrm{~N}\right.$-nitrate) of Lake Constance [24].

Epilog proposal of "Candidatus Nitrosopumilus limneticus" Based on its phylogenetic placement, gANI values and habitat preference, we propose a new species name for AOA-LC4: "Candidatus Nitrosopumilus limneticus sp. nov." (lim.ne'ti.cus. N. L. masc. adj. limneticus (from Gr. limne, lake, swamp) belonging to a lake). "Candidatus Nitrosopumilus limneticus" encodes and transcribes genes essential for dissimilatory ammonia oxidation to nitrite and autotrophic $\mathrm{CO}_{2}$ fixation via the 3-hydroxypropionyl/ 4-hydroxybutyryl pathway. Its preferred habitat is the oxygenated hypolimnion of oligotrophic freshwater lakes.

\section{CONCLUSION}

Over the last two decades, reports have accumulated that deep oligotrophic lakes sustain large populations of Nitrososphaeria ("Thaumarchaeota") in their hypolimnion [10, 15-20]. Our study links these large archaeal populations to ammonia oxidation activity and quantifies this important ecosystem service at the single-cell, population, and ecosystem levels. We provide compelling evidence that $A O A$ in a deep oligotrophic lake play an equally important role in the nitrogen cycle-both in terms of their relative abundance and nitrogen fluxes-as their counterparts in marine ecosystems [21, 82]. Lakes are considered sentinels of climate change responding to rising annual temperatures by 
changes in their physical, chemical, and biological properties [83]. Lake Constance is no exception; its surface waters have become increasingly much warmer, with an annual average increase of $0.9^{\circ}$ C observed between 1962 to 2014 [84]. Warming is predicted to continue at $0.03^{\circ} \mathrm{C} \mathrm{y}^{-1}$ resulting in increasing thermal stratification and concomitant increased deoxygenation of deep hypolimnetic waters [84]. Here, we show that ammonia oxidation is a key process in the lake's nitrogen cycle driven by a single freshwater AOA ecotype, designated as "Candidatus Nitrosopumilus limneticus". The results support the general view that alpha diversity of AOA in freshwater lakes is extremely low [85-88]. This raises the question how resilient this ecosystem service is to changes in the physical and chemical properties of freshwater lakes in the face of climate change. Since nitrification prevents the accumulation of harmful ammonium, answers to this question are interlinked with our quest for drinking water supply and the quality of freshwater bodies for fisheries and other lacustrine fauna.

\section{DATA AVAILABILITY}

All metagenome and metatranscriptome sequences as well as annotated MAGs are available at NCBI under bioproject number PRJNA691101. AOA abundance data ( $\mathrm{PPCR})$, total ammonium, nitrate and chlorophyll $a$ concentrations, temperature and oxygen measurements and ammonia oxidation rates for the time span of our study are deposited at PANGAEA (https://doi.org/10.1594/PANGAEA.934577).

\section{REFERENCES}

1. Jetten MSM. The microbial nitrogen cycle. Environ Microbiol. 2008;10:2903-9.

2. Alves RJE, Minh BQ, Urich T, Von Haeseler A, Schleper C. Unifying the global phylogeny and environmental distribution of ammonia-oxidising archaea based on amoA genes. Nat Commun. 2018;9:1-17.

3. Könneke M, Bernhard AE, De La Torre JR, Walker CB, Waterbury JB, Stahl DA. Isolation of an autotrophic ammonia-oxidizing marine archaeon. Nature. 2005;437:543-6.

4. Bock $E$, Wagner M. Oxidation of inorganic nitrogen compounds as an energy source. The Prokaryotes. 2006;2:457-95.

5. Daims $H$, Lücker $S$, Wagner M. A new perspective on microbes formerly known as nitrite-oxidizing bacteria. Trends Microbiol. 2016;24:699-712.

6. Daims H, Lebedeva EV, Pjevac P, Han P, Herbold C, Albertsen M, et al. Complete nitrification by Nitrospira bacteria. Nature. 2015;528:504-9.

7. Van Kessel MAHJ, Speth DR, Albertsen M, Nielsen PH, Op Den Camp HJM, Kartal B, et al. Complete nitrification by a single microorganism. Nature. 2015;528:555-9.

8. Hou J, Song C, Cao X, Zhou Y. Shifts between ammonia-oxidizing bacteria and archaea in relation to nitrification potential across trophic gradients in two large Chinese lakes (Lake Taihu and Lake Chaohu). Water Res. 2013;47:2285-96.

9. Hugoni $M$, Etien $S$, Bourges $A$, Lepère $C$, Domaizon I, Mallet $C$, et al. Dynamics of ammonia-oxidizing Archaea and Bacteria in contrasted freshwater ecosystems. Res Microbiol. 2013;164:360-70.

10. Mukherjee M, Ray A, Post AF, McKay RM, Bullerjahn GS. Identification, enumeration and diversity of nitrifying planktonic archaea and bacteria in trophic end members of the Laurentian Great Lakes. J Gt Lakes Res. 2016;42:39-49.

11. Okazaki Y, Nakano SI. Vertical partitioning of freshwater bacterioplankton community in a deep mesotrophic lake with a fully oxygenated hypolimnion (Lake Biwa, Japan). Environ Microbiol Rep. 2016;8:780-8.

12. Vissers EW, Anselmetti FS, Bodelier PLE, Muyzer G, Schleper C, Tourna M, et al. Temporal and spatial coexistence of archaeal and bacterial amoA genes and gene transcripts in Lake Lucerne. Archaea. 2013;2013:289478.

13. Yang Y, Li N, Zhao Q, Yang M, Wu Z, Xie S, et al. Ammonia-oxidizing archaea and bacteria in water columns and sediments of a highly eutrophic plateau freshwater lake. Environ Sci Pollut Res. 2016;23:15358-69.

14. Gwak JH, Jung MY, Hong H, Kim JG, Quan ZX, Reinfelder JR, et al. Archaeal nitrification is constrained by copper complexation with organic matter in municipal wastewater treatment plants. ISME J. 2020;14:335-46.

15. Alfreider A, Grimus V, Luger M, Ekblad A, Salcher MM, Summerer M. Autotrophic carbon fixation strategies used by nitrifying prokaryotes in freshwater lakes. FEMS Microbiol Ecol. 2018;94:1-12.

16. Herber J, Klotz F, Frommeyer B, Weis S, Straile D, Kolar A, et al. A single Thaumarchaeon drives nitrification in deep oligotrophic Lake Constance. Environ Microbiol. 2020;22:212-28.

17. Callieri C, Hernández-Avilés S, Salcher MM, Fontaneto D, Bertoni R. Distribution patterns and environmental correlates of Thaumarchaeota abundance in six deep subalpine lakes. Aquat Sci. 2016;78:215-25.
18. Pollet T, Berdjeb L, Chardon C, Jacquet S. Contrasting temporal patterns in ammonia-oxidizing archaeal community dynamics in two peri-alpine lakes with different trophic status. Aquat Micro Ecol. 2018;81:95-108.

19. Small GE, Bullerjahn GS, Sterner RW, Beall BFN, Brovold S, Finlay JC, et al. Rates and controls of nitrification in a large oligotrophic lake. Limnol Oceanogr. 2013;58:276-86.

20. Urbach E, Vergin KL, Young L, Morse A, Larson GL, Giovannoni SJ. Unusual bacterioplankton community structure in ultra-oligotrophic Crater Lake. Limnol Oceanogr. 2001;46:557-72.

21. Karner MB, DeLong EF, Karl DM. Archaeal dominance in the mesopelagic zone of the Pacific Ocean. Nature. 2001;409:507-10.

22. Lehtovirta-Morley LE. Ammonia oxidation: Ecology, physiology, biochemistry and why they must all come together. FEMS Microbiol Lett. 2018;365:1-9.

23. Petri M. Water Quality of Lake Constance. The Rhine. 2006. Springer Berlin Heidelberg, Berlin, Heidelberg, pp 127-38.

24. Güde $H$, Straile D. Bodensee Ökologie und anthropogene Belastungen eines tiefen Voralpensees. 2016. Schweizerbart Science Publishers, Stuttgart, Germany.

25. Rinke C, Chuvochina M, Mussig AJ, Chaumeil P-A, Davín AA, Waite DW, et al. A standardized archaeal taxonomy for the Genome Taxonomy Database. Nat Microbiol. 2021;6:946-59.

26. Schneider D, Wemheuer F, Pfeiffer B, Wemheuer B. Extraction of total DNA and RNA from marine filter samples and generation of a CDNA as universal template for marker gene studies. Methods Mol Biol. 2017;1539:13-22.

27. Beam JP Geobiological interactions of archaeal populations in acidic and alkaline geothermal springs of Yellowstone National Park, WY, USA. 2015. Montana State University.

28. Sauder LA, Albertsen M, Engel K, Schwarz J, Nielsen PH, Wagner M, et al. Cultivation and characterization of Candidatus Nitrosocosmicus exaquare, an ammonia-oxidizing archaeon from a municipal wastewater treatment system. ISME J. 2017:11:1142-57.

29. Wallner G, Amann R, Beisker W. Optimizing fluorescent in situ hybridization with rRNA-targeted oligonucleotide probes for flow cytometric identification of microorganisms. Cytometry. 1993;14:136-43.

30. Pernthaler A, Pernthaler J, Amann R Sensitive multi-color fluorescence in situ hybridization for the identification of environmental microorganisms. In: Kowalchuk G, de Bruijn FJ, Head IM, Akkermans ADL, van Elsas JD (eds). Molecular Microbial Ecology Manual, 2nd ed. 2004. Kluwer Academic Publishers, Dordrecht, Boston, London, pp 711-26.

31. Kitzinger K, Padilla CC, Marchant HK, Hach PF, Herbold CW, Kidane AT, et al. Cyanate and urea are substrates for nitrification by Thaumarchaeota in the marine environment. Nat Microbiol. 2019;4:234-43.

32. Kempers AJ, Kok CJ. Re-examination of the determination of ammonium as the indophenol blue complex using salicylate. Anal Chim Acta. 1989;221:147-55.

33. Warembourg FR. Nitrogen fixation in soil and plant systems. Nitrogen Isotope Techniques. 1993;654:157-80.

34. Füssel J, Lam $P$, Lavik $G$, Jensen $M M$, Holtappels $M$, Günter $M$, et al. Nitrite oxidation in the Namibian oxygen minimum zone. ISME J. 2012;6:1200-9.

35. Mcllvin MR, Altabet MA. Chemical conversion of nitrate and nitrite to nitrous oxide for nitrogen and oxygen isotopic analysis in freshwater and seawater. Anal Chem. 2005;77:5589-95.

36. Kitzinger K, Tienken D, Littmann S, Kidane AT, Kuypers MMM, Milucka J. Assigning function to phylogeny: FISH-nanoSIMS. Methods Mol Biol. 2021;2246:207-24.

37. Martínez-Pérez C, Mohr W, Löscher CR, Dekaezemacker J, Littmann S, Yilmaz $P$, et al. The small unicellular diazotrophic symbiont, UCYN-A, is a key player in the marine nitrogen cycle. Nat Microbiol. 2016;1:1-7.

38. Polerecky L, Adam B, Milucka J, Musat N, Vagner T, Kuypers MMM. Look@NanoSIMS - a tool for the analysis of nanoSIMS data in environmental microbiology. Environ Microbiol. 2012;14:1009-23.

39. Kitzinger K, Marchant HK, Bristow LA, Herbold CW, Padilla CC, Kidane AT, et al. Single cell analyses reveal contrasting life strategies of the two main nitrifiers in the ocean. Nat Commun 2020;11:1-12.

40. Musat N, Foster R, Vagner T, Adam B, Kuypers MMM. Detecting metabolic activities in single cells, with emphasis on nanoSIMS. FEMS Microbiol Rev. 2012;36:486-511.

41. Woebken D, Burow LC, Behnam F, Mayali X, Schintlmeister A, Fleming ED, et al. Revisiting $\mathrm{N}_{2}$ fixation in Guerrero Negro intertidal microbial mats with a functional single-cell approach. ISME J. 2015;9:485-96.

42. Meyer NR, Fortney JL, Dekas AE. NanoSIMS sample preparation decreases isotope enrichment: magnitude, variability and implications for single-cell rates of microbial activity. Environ Microbiol. 2021;23:81-98.

43. Khachikyan A, Milucka J, Littmann S, Ahmerkamp S, Meador T, Könneke M, et al. Direct cell mass measurements expand the role of small microorganisms in nature. Appl Environ Microbiol. 2019;85:1-12.

44. Sun J, Liu D. Geometric models for calculating cell biovolume and surface area for phytoplankton. J Plankton Res. 2003;25:1331-46. 
45. Jakobsen $\mathrm{HH}$, Markager S. Carbon-to-chlorophyll ratio for phytoplankton in temperate coastal waters: Seasonal patterns and relationship to nutrients. Limnol Oceanogr. 2016;61:1853-68.

46. Herbold CW, Lehtovirta-Morley LE, Jung MY, Jehmlich N, Hausmann B, Han P, et al. Ammonia-oxidising archaea living at low $\mathrm{pH}$ : Insights from comparative genomics. Environ Microbiol. 2017;19:4939-52.

47. Parks DH, Imelfort M, Skennerton CT, Hugenholtz P, Tyson GW. CheckM: assessing the quality of microbial genomes recovered from isolates, single cells, and metagenomes. Genome Res. 2015;25:1043-55.

48. Brown CT, Olm MR, Thomas BC, Banfield JF. Measurement of bacterial replication rates in microbial communities. Nat Biotechnol. 2016;34:1256-63.

49. Long AM, Hou S, Ignacio-Espinoza JC, Fuhrman JA. Benchmarking microbial growth rate predictions from metagenomes. ISME J. 2021;15:183-95.

50. Emiola A, Oh J. High throughput in situ metagenomic measurement of bacterial replication at ultra-low sequencing coverage. Nat Commun. 2018;9:4956.

51. Gao Y, Li H. Quantifying and comparing bacterial growth dynamics in multiple metagenomic samples. Nat Methods. 2018;15:1041-4.

52. Könneke M, Schubert DM, Brown PC, Hügler $M$, Standfest $S$, Schwander $T$, et al. Ammonia-oxidizing archaea use the most energy-efficient aerobic pathway for $\mathrm{CO}_{2}$ fixation. Proc Natl Acad Sci. 2014;111:8239-44.

53. Walker CB, De La Torre JR, Klotz MG, Urakawa H, Pinel N, Arp DJ, et al. Nitrosopumilus maritimus genome reveals unique mechanisms for nitrification and autotrophy in globally distributed marine crenarchaea. Proc Natl Acad Sci. 2010;107:8818-23.

54. Carini $P$, Dupont $C L$, Santoro AE. Patterns of thaumarchaeal gene expression in culture and diverse marine environments. Environ Microbiol. 2018;20:2112-24.

55. Kozlowski JA, Stieglmeier M, Schleper C, Klotz MG, Stein LY. Pathways and key intermediates required for obligate aerobic ammonia-dependent chemolithotrophy in bacteria and Thaumarchaeota. ISME J. 2016;10:1836-45.

56. Pester M, Maixner F, Berry D, Rattei T, Koch H, Lücker $\mathrm{S}$, et al. NxrB encoding the beta subunit of nitrite oxidoreductase as functional and phylogenetic marker for nitrite-oxidizing Nitrospira. Environ Microbiol. 2014;16:3055-71.

57. Dimitri Kits K, Sedlacek CJ, Lebedeva EV, Han P, Bulaev A, Pjevac P, et al. Kinetic analysis of a complete nitrifier reveals an oligotrophic lifestyle. Nature. 2017;549:269-72.

58. Jung M-Y, Sedlacek CJ, Kits KD, Mueller AJ, Rhee S-K, Hink L, et al. Ammoniaoxidizing archaea possess a wide range of cellular ammonia affinities. ISME J. 2021. https://doi.org/10.1038/s41396-021-01064-z.

59. Costa E, Pérez J, Kreft JU. Why is metabolic labour divided in nitrification? Trends Microbiol. 2006;14:213-9.

60. Simon M. Growth characteristics of small and large free-living and attached bacteria in Lake Constance. Micro Ecol. 1988;15:151-63.

61. Stein LY. Insights into the physiology of ammonia-oxidizing microorganisms. Curr Opin Chem Biol. 2019;49:9-15.

62. Alonso-Sáez L, Waller AS, Mende DR, Bakker K, Farnelid H, Yager PL, et al. Role for urea in nitrification by polar marine Archaea. Proc Natl Acad Sci. 2012;109:17989-94.

63. Herndl GJ, Reinthaler T, Teira E, van Aken H, Veth C, Pernthaler A, et al. Contribution of archaea to total prokaryotic production in the deep Atlantic Ocean. Appl Environ Microbiol. 2005;71:2303-9.

64. Berg C, Listmann L, Vandieken V, Vogts A, Jürgens K. Chemoautotrophic growth of ammonia-oxidizing Thaumarchaeota enriched from a pelagic redox gradient in the Baltic Sea. Front Microbiol. 2014;5:1-10.

65. Bayer B, Vojvoda J, Reinthaler T, Reyes C, Pinto M, Herndl GJ. Nitrosopumilus adriaticus sp. nov. and Nitrosopumilus piranensis sp. nov., two ammonia-oxidizing archaea from the adriatic sea and members of the class Nitrososphaeria. Int J Syst Evol Microbiol. 2019;69:1892-902.

66. White AE, Giovannoni SJ, Zhao Y, Vergin K, Carlson CA. Elemental content and stoichiometry of SAR11 chemoheterotrophic marine bacteria. Limnol Oceanogr Lett. 2019;4:44-51.

67. Burg TP, Godin M, Knudsen SM, Shen W, Carlson G, Foster JS, et al. Weighing of biomolecules, single cells and single nanoparticles in fluid. Nature. 2007;446:1066-9.

68. Sterner R. C:N:P stoichiometry in Lake Superior: freshwater sea as end member. Inl Waters. 2011;1:29-46.

69. Vincent WF, Downes MT. Nitrate accumulation in aerobic hypolimnia: Relative importance of benthic and planktonic nitrifiers in an oligotrophic lake. Appl Environ Microbiol. 1981;42:565-73.

70. Clark DR, Rees AP, Joint I. Ammonium regeneration and nitrification rates in the oligotrophic Atlantic Ocean: Implications for new production estimates. Limnol Oceanogr. 2008;53:52-62.

71. Newell SE, Fawcett SE, Ward BB. Depth distribution of ammonia oxidation rates and ammonia-oxidizer community composition in the Sargasso Sea. Limnol Oceanogr Lett. 2013;58:1491-1500.
72. Raimbault P, Slawyk G, Boudjellal B, Coatanoan C, Conan P, Coste B, et al. Carbon and nitrogen uptake and export in the equatorial Pacific at $150^{\circ} \mathrm{W}$ : Evidence of an efficient regenerated production cycle. J Geophys Res. 1999;104:3341-56.

73. Santoro AE, Saito MA, Goepfert TJ, Lamborg CH, Dupont CL, DiTullio GR. Thaumarchaeal ecotype distributions across the equatorial Pacific Ocean and their potential roles in nitrification and sinking flux attenuation. Limnol Oceanogr. 2017;62:1984-2003.

74. Carini SA, Joye SB. Nitrification in Mono Lake, California: Activity and community composition during contrasting hydrological regimes. Limnol Oceanogr. 2008;53:2546-57.

75. Massé $S$, Botrel $M$, Walsh DA, Maranger R. Annual nitrification dynamics in a seasonally ice-covered lake. PLoS One. 2019;14:1-21.

76. Cavaliere E, Baulch HM. Winter nitrification in ice-covered lakes. PLoS One. 2019;14:1-20.

77. Hampel JJ, McCarthy MJ, Gardner WS, Zhang L, Xu H, Zhu G, et al. Nitrification and ammonium dynamics in Taihu Lake, China: Seasonal competition for ammonium between nitrifiers and cyanobacteria. Biogeosciences. 2018;15:733-48.

78. Wuchter C, Abbas B, Coolen MJL, Herfort L, Van Bleijswijk J, Timmers P, et al. Archaeal nitrification in the ocean. Proc Natl Acad Sci. 2006;103:12317-22.

79. Adam G, Läuger P, Stark G Physikalische Chemie und Biophysik. 2009. Springer, Heidelberg.

80. Häse C, Gaedke U, Seifried A, Beese B, Tilzer MM. Phytoplankton response to reoligotrophication in large and deep Lake Constance: Photosynthetic rates and chlorophyll concentrations. Arch für Hydrobiol. 1998;53:159-78.

81. Bührer H, Kirner P, Wagner G. Dem Bodensee in den Abflussjahren 1996 und 1997 zugeführte Stofffrachten. Ber der Int Gewässerschutzkommission für den Bodensee. 2000;53:1-43.

82. Brochier-Armanet C, Boussau B, Gribaldo S, Forterre $P$, Tourna $M$, Stieglmeier $M$, et al. A standardized bacterial taxonomy based on genome phylogeny substantially revises the tree of life. ISME J. 2018;9:1-15.

83. Williamson CE, Saros JE, Vincent WF, Smol JP. Lakes and reservoirs as sentinels, integrators, and regulators of climate change. Limnol Oceanogr. 2009;54:2273-82.

84. Fink G, Fleig $M$, Lang $U$, Mirbach S, Schick R, Wahl B, et al. KlimBo - Klimawandel am Bodensee. IGKB - Blaue R 2015;60.

85. Auguet JC, Triadó-Margarit X, Nomokonova N, Camarero L, Casamayor EO. Vertical segregation and phylogenetic characterization of ammonia-oxidizing Archaea in a deep oligotrophic lake. ISME J. 2012;6:1786-97.

86. Coci M, Odermatt N, Salcher MM, Pernthaler J, Corno G. Ecology and distribution of Thaumarchaea in the deep hypolimnion of Lake Maggiore. Archaea. 2015;2015:590434.

87. Vissers EW, Blaga Cl, Bodelier PLEE, Muyzer G, Schleper C, Sinninghe Damsté JS et al. Seasonal and vertical distribution of putative ammonia-oxidizing thaumarchaeotal communities in an oligotrophic lake. FEMS Microbiol Ecol. 2013;83:515-26.

88. Restrepo-Ortiz CX, Auguet J-C, Casamayor EO. Targeting spatiotemporal dynamics of planktonic SAGMGC-1 and segregation of ammonia-oxidizing thaumarchaeota ecotypes by newly designed primers and quantitative polymerase chain reaction. Environ Microbiol. 2014;16:689-700.

89. Nguyen L-T, Schmidt HA, von Haeseler A, Minh BQ. IQ-TREE: a fast and effective stochastic algorithm for estimating maximum-likelihood phylogenies. Mol Biol Evol. 2014;32:268-74.

\section{ACKNOWLEDGEMENTS}

We thank Alfred Sulger as captain of the RV Robert Lauterborn, Joseph Halder, Sylke Wiechmann, Julia Schmidt, Christian Fiek, Isabell Winter, Gabriele Glockgether, Nadine Rujanski, Fenna Alfke, Tine Jordan and Pia Mahler for technical support. We thank Dietmar Straile for provision of chlorophyll $a$ data and scientific exchange, Holger Daims and Soeren Ahmerkamp for fruitful discussions as well as David Schleheck for providing laboratory space. This research was funded by the German Research Foundation (DFG, GRK 2272/1, project C2 to MP and BS), the University of Konstanz, the Leibniz Institute DSMZ, and the Max Planck Society.

\section{AUTHOR CONTRIBUTIONS}

FK, KK, BS, MMMK, and MP designed the study; PB performed sequencing and sequencing library preparations and measured total ammonium; KK and SL ran nanoSIMS analyses; FK, KK, DKN, and MP analyzed samples and data. The manuscript was written by FK and MP with contributions from all co-authors. 


\section{6}

\section{FUNDING}

Open Access funding enabled and organized by Projekt DEAL.

\section{COMPETING INTERESTS}

The authors declare no competing interests.

\section{ADDITIONAL INFORMATION}

Supplementary information The online version contains supplementary material available at https://doi.org/10.1038/s41396-022-01216-9.

Correspondence and requests for materials should be addressed to Michael Pester.

Reprints and permission information is available at http://www.nature.com/ reprints
Publisher's note Springer Nature remains neutral with regard to jurisdictional claims in published maps and institutional affiliations.

(i) Open Access This article is licensed under a Creative Commons Attribution 4.0 International License, which permits use, sharing, adaptation, distribution and reproduction in any medium or format, as long as you give appropriate credit to the original author(s) and the source, provide a link to the Creative Commons license, and indicate if changes were made. The images or other third party material in this article are included in the article's Creative Commons license, unless indicated otherwise in a credit line to the material. If material is not included in the article's Creative Commons license and your intended use is not permitted by statutory regulation or exceeds the permitted use, you will need to obtain permission directly from the copyright holder. To view a copy of this license, visit http://creativecommons.org/licenses/by/4.0/.

(c) The Author(s) 2022 